\section{SOI: $1.1 /$ TAS DOI: $10.15863 /$ TAS International Scientific Journal Theoretical \& Applied Science}

p-ISSN: 2308-4944 (print) e-ISSN: 2409-0085 (online)

Year: $2015 \quad$ Issue: 04 Volume: 24

Published: $30.04 .2015 \quad$ http://T-Science.org

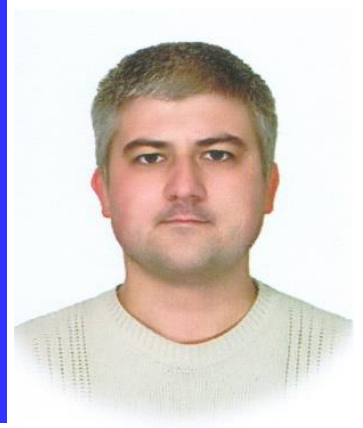

Alexey A. Ryzhenko

Research associate, Candidate of technical sciences, State Fire Academy of EMERCOM of Russia, Russia litloc@rambler.ru

Natalya Y. Ryzhenko Associate professor of IT, Candidate of technical sciences, SFA of EMERCOM of Russia

SECTION 4. Computer science, computer engineering and automation.
Nikolay A. Matveev

Associate professor of IT, Candidate of pedagogical sciences,

SFA of EMERCOM of Russia

\title{
SIMULATION PLANNING OF THE LEARNING PROCESS
}

Abstract: The mechanism of modeling processes of the educational environment is present in article. Feature of model is the specialization and systematization of each element within the common total goal that gives the chance accurately to represent a training result.

Key words: system of systems, educational process, theory of sets.

Language: English

Citation: Ryzhenko AA, Ryzhenko NY, Matveev NA (2015) SIMULATION PLANNING OF THE LEARNING PROCESS. ISJ Theoretical \& Applied Science 04 (24): 86-93.

Soi: http://s-o-i.org/1.1/TAS*04(24)15 Doi: crossef http://dx.doi.org/10.15863/TAS.2015.04.24.15

\section{Introduction}

Tendencies of fast development of a modern education system dictate new rules to participants of process. The classical system of training in the conditions of constant pressure from labor market does not maintain an infinite impact, hands over positions of the stable general school approved decades. Indicators of literacy fall in a geometrical progression every year that especially is well noticeable in profile professions and specialties. Experts even more often establish that fact that in the course of training "there is nobody to impart knowledge, don't want to study". Thus, the society tries "to train" teachers, but not younger generation.

On the other hand, if to look at the put problem in a complex, it is possible to track that fact that a source of the accruing negative society. A striking example mass sources of information (mass media, the Internet, etc.) pursue now only one aim not to force society to think and reflect over events or the current situation, to propose only ready solutions. This factor eliminates opportunity to think at an early stage of development of brain activity that further can be restore only in case of full refusal of external reality. As a result, getting to educational institution where process of training demands self-development, rejection begins an organism of an external source of information as irritant.

The put restrictions demand to modify training process, to base a discipline component on ready decisions, to prove each step, etc. As a result, the staff of educational institutions together with teaching structure is compelled to spend the most part of time not on preparation for occupations, and on registration of infinitely accruing accompanying documentation in the conditions of constantly changing external requirements.

Exits from a situation the set is offer. In this work, the modified system of training within the total purpose of training is considered. Feature of methodology is fast adaptability to the changing conditions, and the accounting of possible external impacts on the training process operating in real time.

\section{Concept of methodology}

Feature of the described direction is positioning stages of process of training from a closing stage, which is from achievement of the total purpose. It is suppose that in this case the trainee, since a receipt stage accurately represents for what he studies, and that as a result can receive. Thus, it is necessary to understand that training process, as a live organism has to work constantly is not dependent on influences of trainees and environment. Any essential influence causes only negative reaction that leads to operation of a protective reflex and rejection of the introduced element. Moreover, each participant has to realize the importance in the organization of educational process. Only by properly these factors can be transmitted systematic knowledge. 
Consider systematically as it is possible to enter changes into the existing education system without breaking integrity of the current educational process. Classically, training of specialists is base by the principle of hierarchical transfer of knowledge in the form of the truncated pyramid where elements are disciplines of specialty (Fig. 1). As a rule, the lower circles are fill with the general disciplines. Than the course is more senior, those remain less general disciplines. At the same time, special disciplines fill circles on the contrary - the course is more senior, it is more than disciplines. Each discipline irrespective of number of the allocated hours provides knowledge in theoretical (lecture occupations) and a practical form (practical and seminary training). Unfortunately, often it happens so that some disciplines contradict each other, or present the same information different volumes. Both that and other case brings additional confusion in training process, in delivery of knowledge by the trainee that is undesirable during continuous changes of conditions of a foreign market.

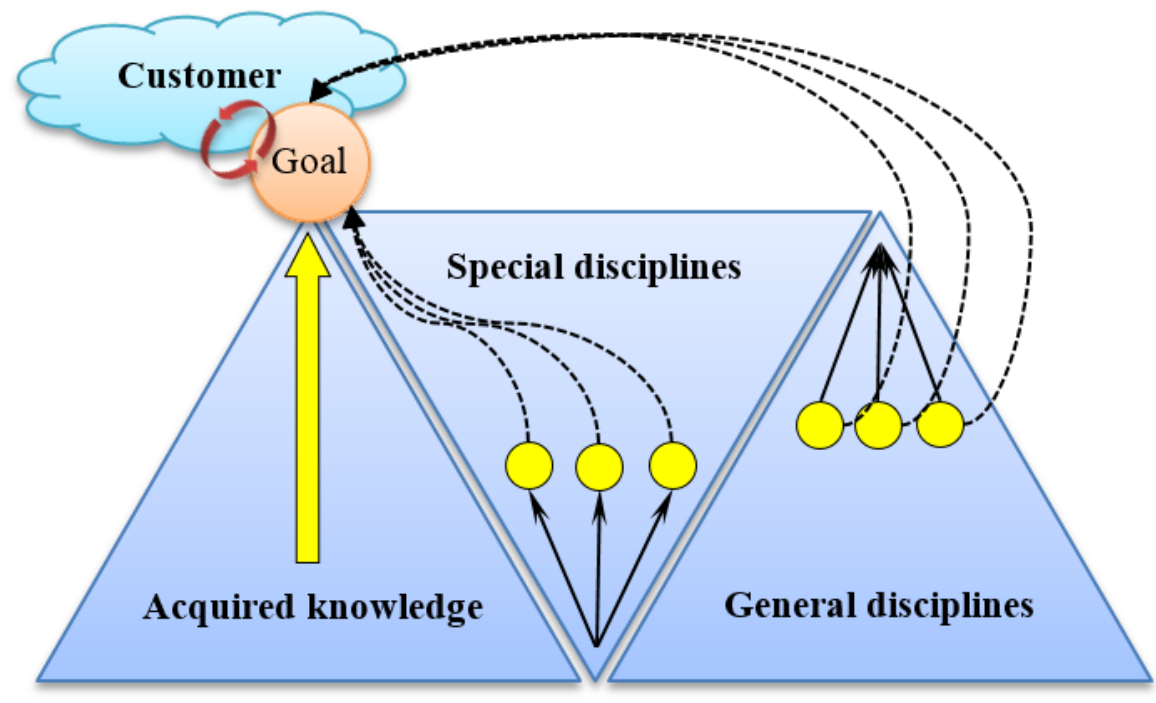

Figure 1 - Formation of process of training from a result.

The version of the decision offers entering into each discipline of a definite purpose that will be at the same time one or several tasks that decision will allow to achieve the total objectives of training on the chosen specialty (Fig. 1). Consider in more detail this form of finishing information.

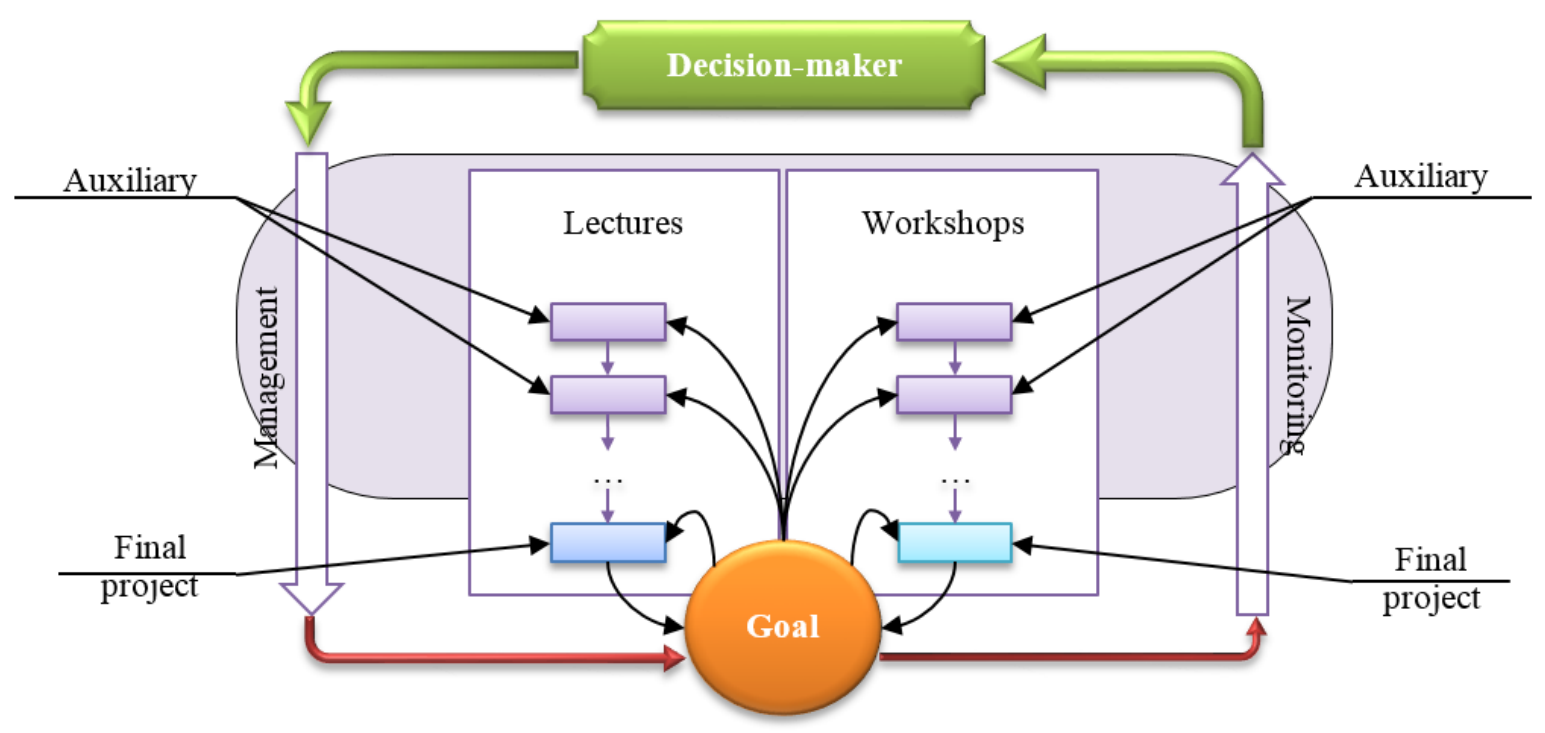

Figure 2 - Structure management of integrity of one discipline. 
It is suppose that creation of any discipline has to be base systemically, beginning from the total purpose. In this case, it is convenient to use a method of projects as the instrument of bringing to the final solution of the put problem (Fig. 2). The offered approach is in detail presented in works $[1,2]$. As the final project either the term paper, or a complex task, which decision can be used all list of the thematic directions, or other form of practical introduction of the gained knowledge within one discipline covers. Thus, a certain quantity practical (and/or laboratory) tasks in each discipline is allocate as bringing under tasks of the finishing project.

For introduction of the offered approach in a discipline, there is no need of introduction of any essential changes. We will consider some possible scenarios:

- modification only of practical part. This scenario generally belongs to special disciplines. When developing accompanying documents the purpose of a discipline will be transformed to the purpose of the final project, other tasks bringing i.e. are used only in the disciplines;

- modification of course contents. This scenario can be use both for special, and for the main disciplines. Feature is use of descriptive part of fragments of a concluding session, both in practical, and in theoretical part. For example, the final project in the form of a complex task is suppose with public protection. On practical part the project is developed, and on the theoretical there is a preparation of abstract part.

Expand further the presented task to the level of one allocated specialty. When using of the offered method the following scenario is possible: the head of faculty (or chairs) appoints the total purpose of training of specialists on a certain profile to a certain stream, then builds a hierarchical tree of disciplines, divides tasks for each discipline, carries out monitoring and the analysis of process of training. In this case, for the system is easy to use learning through project method present in [2]. Feature of a method is some commonality. It is supposed that, despite integrity of process of training, each discipline, in own way, it is autonomous. Moreover, some disciplines can make an autonomous cycle of disciplines (Fig. 3). Convenience of this mechanism also that when transfer trainees from one specialty or the program on another the accounting of the mastered competences is already provided.

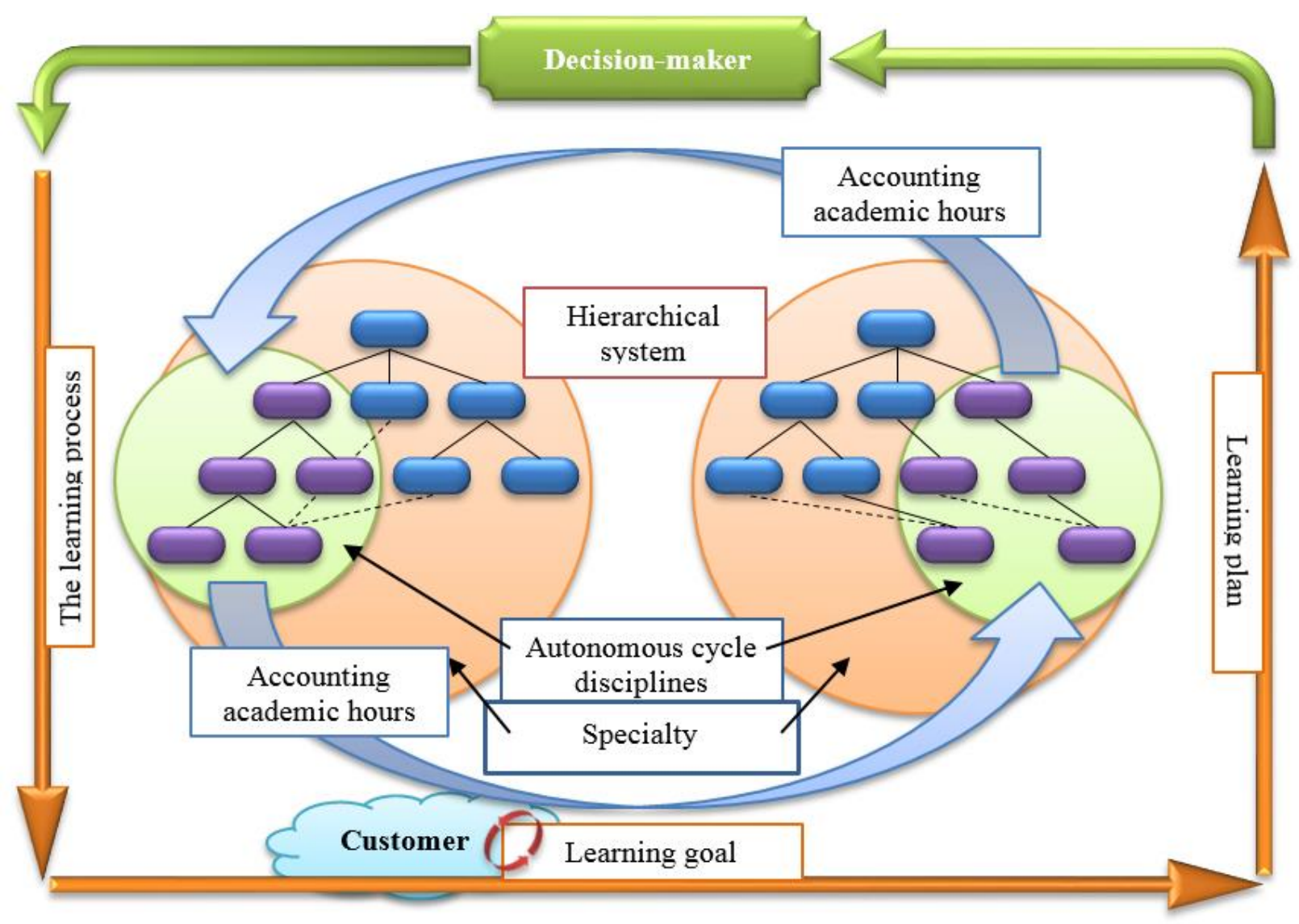

Figure 3 - Structure management of integrity of process of training. 
Nevertheless, when modeling complete information system of the educational environment there is a problem of the description of processes of training as separate elements, independent of objects. Abstract structures it is almost impossible (without introduction of additional rules or conditions) to describe such processes, as, for example, the repeated delivery of session which is dragged out on some semester, material fixing with occupations unaccounted earlier, transfer of occupations taking into account replacement of the teacher or expeditious introduction of additional hours in connection with shortage for development of the chosen competence. The existing approaches and methodologies of creation of difficult systems mean a rigid binding of all elements (objects, processes and resources) to the standard mechanism of "a black box". Thus, the hierarchical system of elements with possibility of alternative combinations that is not always convenient in the developing systems is meant. In this methodology use of facet system of [3] organizations of objects or the system presented in the form of the interconnected tables in which cells the operated profile processes (Fig. 4) are put is meant.

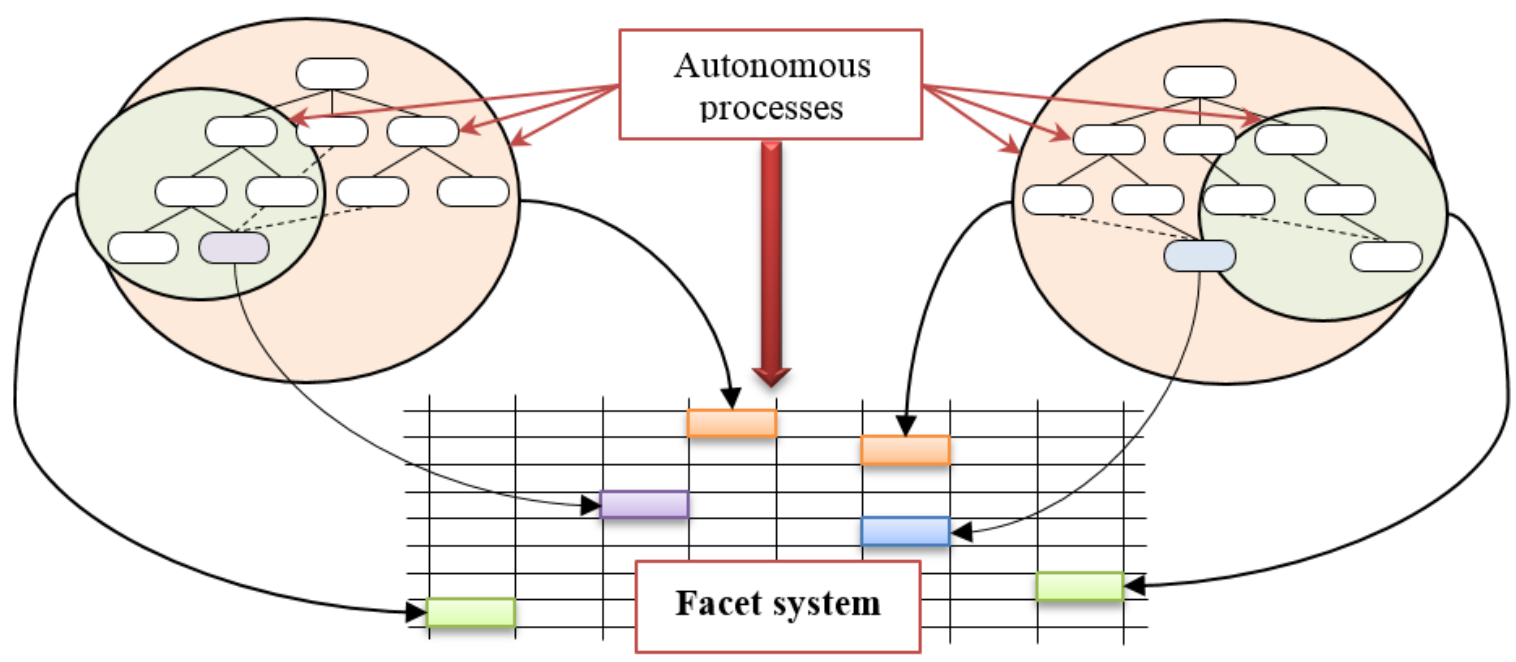

Figure 4 - Methodology of use of facet system.

Feature of facet system is its immunity to fast modifications in structure that significantly affects at constant and periodic modification of the existing structure of processes. This system developed together with hierarchical, but due to the complexity of accounting elements accepted unpopular character in system of integrated management.

Nevertheless, fast development of information technologies allowed using difficult analytical and logical transformations to the shortest time that is important in the complex analysis of difficult systems [4]. As a result, the facet system occupied one of the leading roles in the organization of big data flows over time. A typical example are SQL inquiries of control systems of bases and storages of data.

In the educational environment of a cell facet system it is also used now by comparison of competences of specialty of standards to class periods of disciplines. Practice showed that because of establishment of communications, as a rule, we receive network model where the set of crossings and imposing is available. Features of creation of hierarchical models which do not allow to change quickly established connection are the reason (as a rule, change of one communication attracts change of all of structure, underlying on hierarchy of a tree) with use of constant parameters educational process. Therefore, for decision-making at modification of the operating educational process (without analysis of additional diversity), it is rational to use complex model where competences as the defining parameter are built hierarchically, and the corresponding disciplines are dispersed in a cellular form (Fig. 5). 


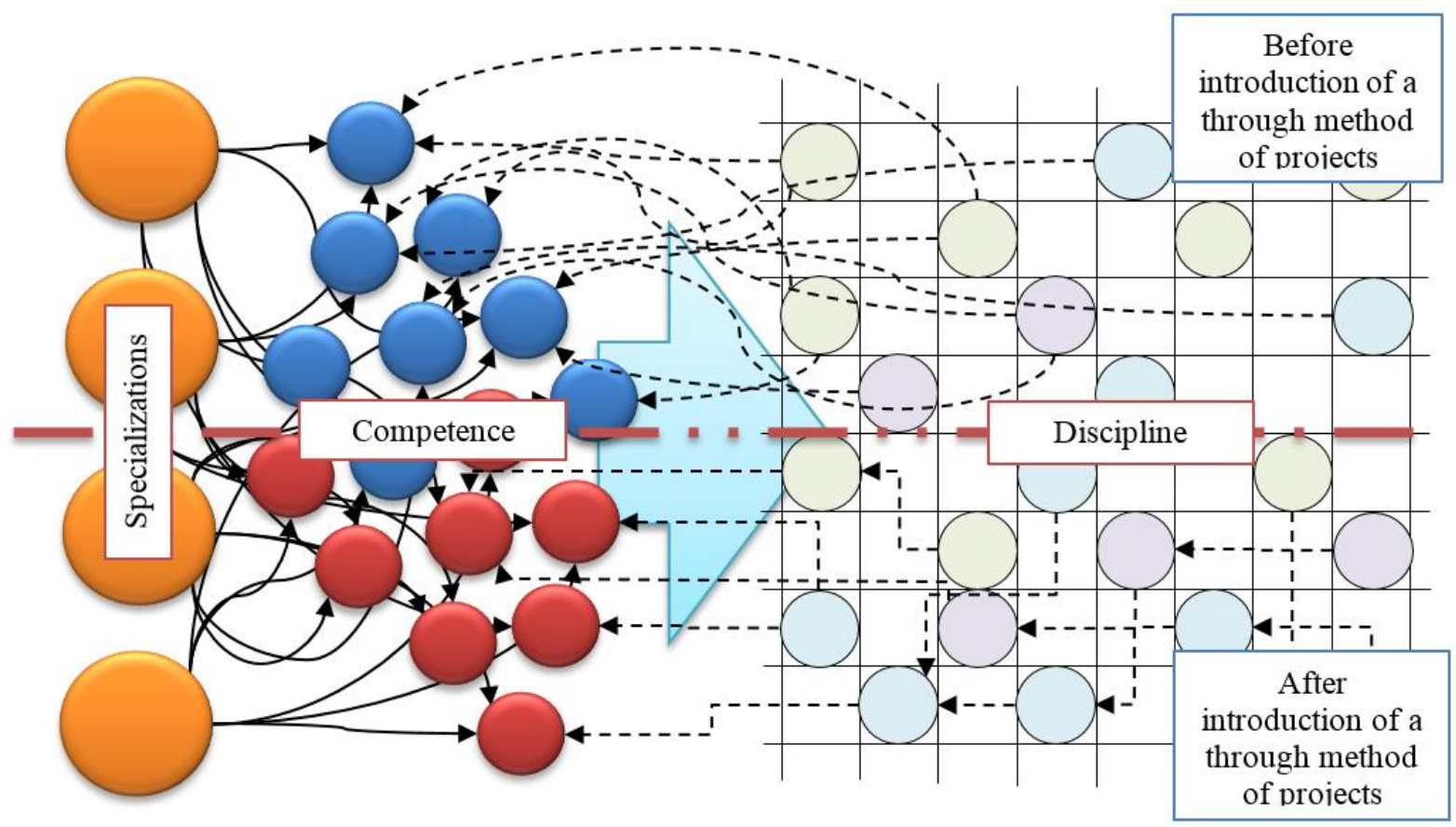

Figure 5 - Complex use of structuring data.

Now practically there are no the models and methods allowing to formalize facet systems of coordination of the operated processes. Further, the new approach allowing considering and systematizing similar transformations is offer (Fig. 6).

The considered methodology is based on the theory of sets from whole, offered by Kolmogorov
A.N. [5], and concept of elements-systems of Vavilov N.A. [6]. As one of the key principles the process model repetition, i.e. a call of the same action several times is putting. Because of processing, we have an opportunity to unite or reduce the identical and duplicating operated processes. For an objective, the principle can be consider on one simple example [7, 8].

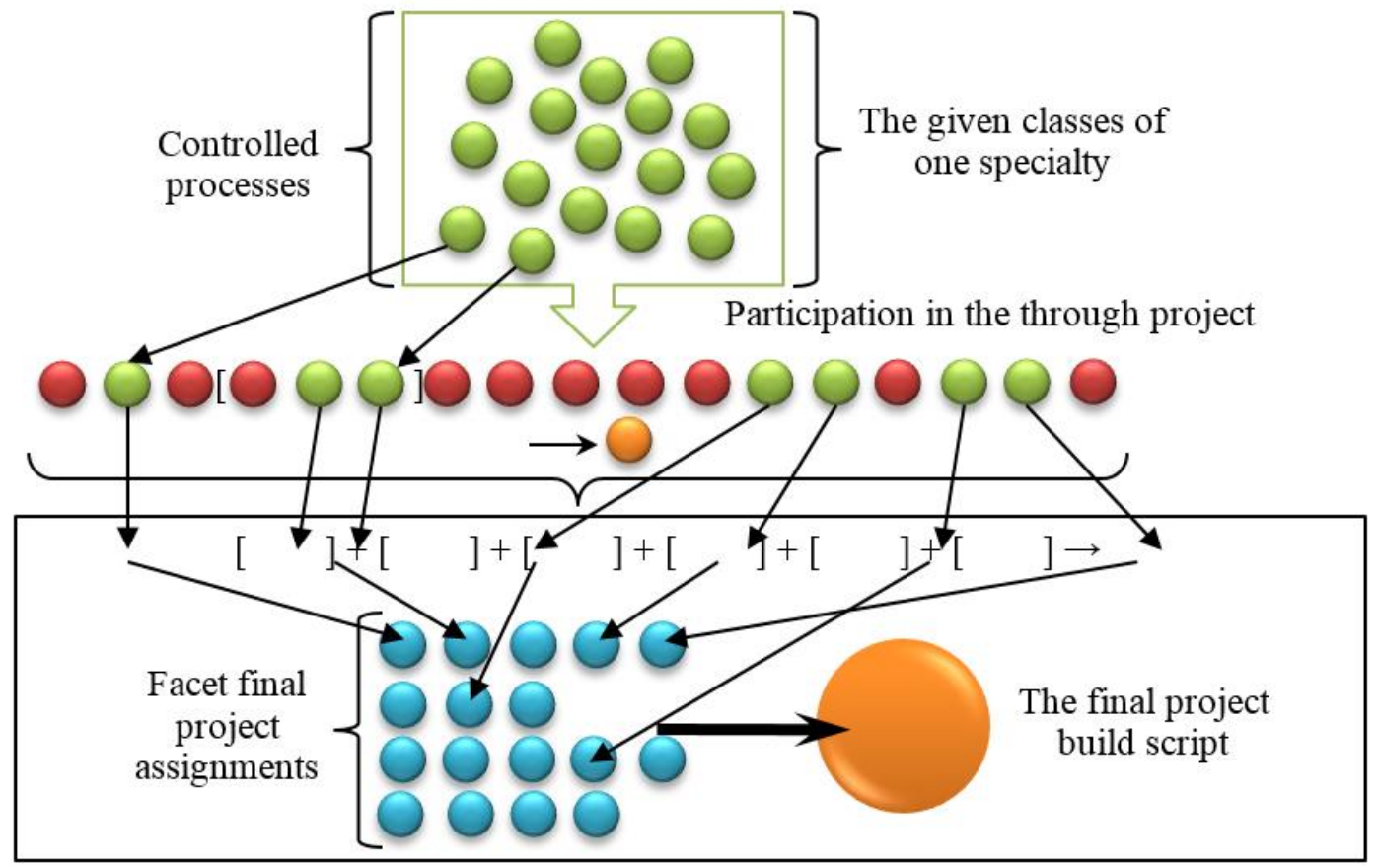

Figure 6 - Scheme methodology systematizing controlled processes.

ISPC The Combination of Technology \&

Education, Östersund, Sweden 
Scenario: use a through method of projects of one stream of any specialty. It is suppose that on all disciplines, independent practical (laboratory) training is conduct, but some of them have to be part of the general (uniform for a stream) the through project.

Task: the final project within one specialty (all 15 tasks include) uses practical results of two disciplines; the solution of five tasks is putting. In the course of training in the first discipline, performance of six laboratory works during a semester is putting by the working program. The project supposes to use only three of them (two intermediate and the third total). Therefore, all six works are perform by trainees, but three of them will be only discipline. On other discipline, five works are putting, and the project uses only two of them and both total. Therefore, three of them only the discipline. The additional condition - the sum of all carried-out works cannot go beyond the put top limit (Fig. 7).
Moreover, to disciplines of this project, it is necessary to conform to the following rules:

- it is impossible to transfer all laboratory works to one discipline;

- the minimum quantity of laboratory works of one disciplines used for the project shouldn't exceed the maximum quantity laboratory the project.

Statement of the problem: it is necessary to construct the short form of logical expression describing process of formation of tasks of the through final project for further modeling.

Formally, final scenario can be present in the rule form [9-11]:

$$
\left[3+2_{15}+1_{15}\right]+\left[3+2_{15}\right] \underset{15}{\rightarrow} 5,
$$

where number behind an arrow - quantity of tasks of the final project, necessary for performance, for these disciplines, and number under an arrow - the maximum quantity of the tasks planned by the project.

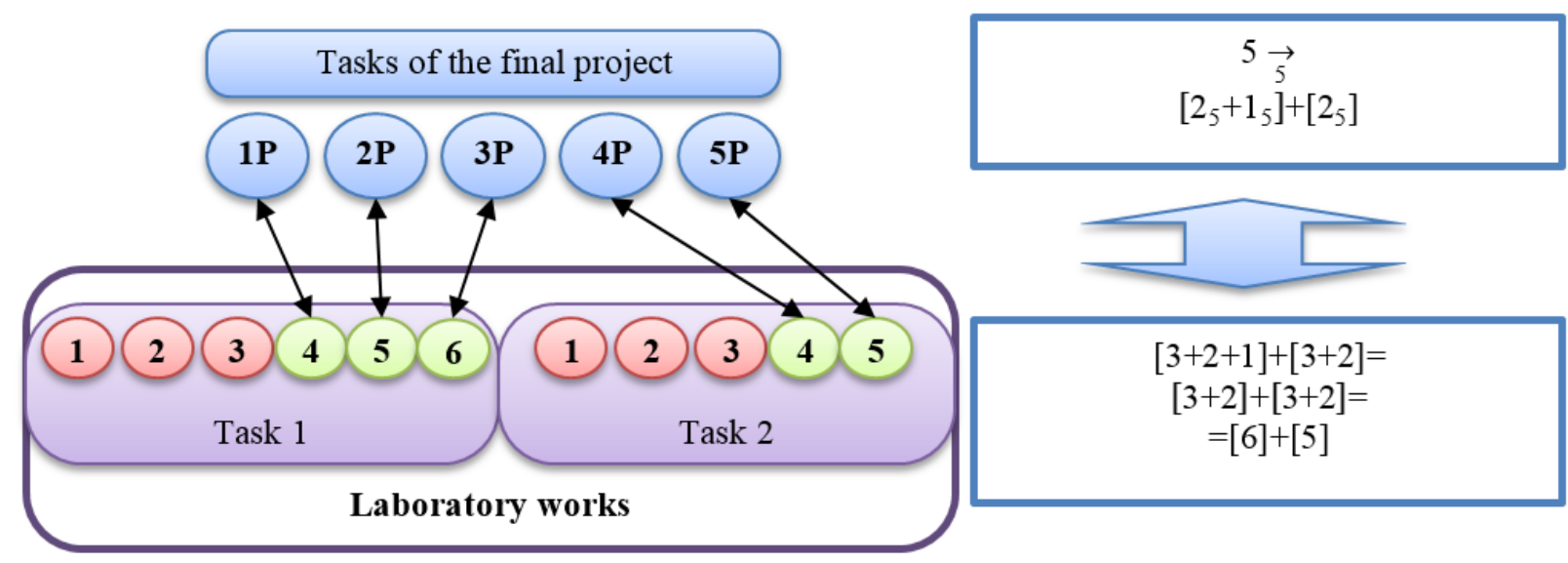

Figure 7 - Schematic submission of the solution of the first task.

The received rule is substitute in a cell of a facet of the final project where it is use if necessary as the instruction for comparison of competences disciplines to the corresponding competences of the standard (Fig. 8). Each cell of a total facet contains compound information on the given classes (type, accessory to a discipline, the description, the purpose, the solved perspective, quantity of the allocated units of competences, etc.). The modelled system (and the user) as a result of use rule receives full information on possible "closing" of the corresponding competence of the standard. 
Educational standard

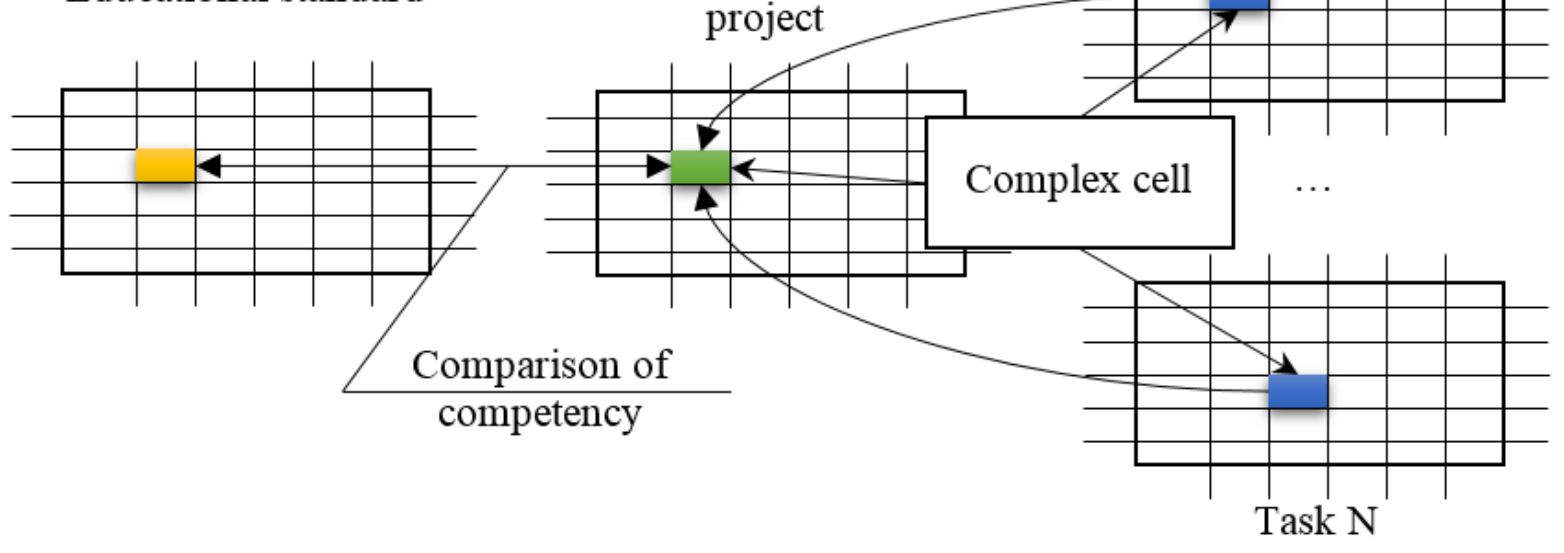

Figure 8 - Comparison of the rule to competence.

As a result, it turns out accurately organized fast with direct access to the elements capable to be compare with demanded in the educational standard to competences. The specialist user (the teacher, the unit manager, chairs, faculty, etc.) receives version of the ready decision for formation of the final target project for each flow of trainees on the allocated specialty.

\section{Conclusion}

Summing up the results on the current solved tasks it is possible to formulate the following conclusions - as a result of introduction offered techniques:

- each trainee knows a training result on the chosen specialty, can formulate the training purpose, and also the importance and relevance solved in the course of tasks;

- the trainee knows that gives each discipline studied by him, what tasks need to be carried out for smooth transition to the following grade level;

- the perspective and the purpose of carrying out occupations of each discipline of specialties allowing to give an adequate assessment to its importance for trainees is accurately defined;

- the hierarchy of disciplines, and also sequence of supply of material taking into account possible intersubjective transitions like "source - a consequence - the solved task" is defined;

- any (additional, variable and so forth) parts of any discipline are developed, since the result determined by the target project that allows to define a possible framework and restrictions;

- the purpose of any discipline of specialty is defined only by the operating person (head), thus there is no need to consider components of the given classes, his concepts and a perspective;

- the discipline is define as the operated process of facet system that allows at possible modifications not to change the main structure and the interacting functionality of educational process.

\section{Acknowledgements}

Russian Federal Property Fund (projects 14-0700205-a, 14-07-00257-a) supported the research work.

\section{References:}

1. Ryzhenko AA, Sepeda-Errero RR (2009) "Structure of the distributed system of information support of education", Applied problems of management of macrosystems: Collected papers ["Struktura raspredelennoj sistemy informacionnoj podderzhki obrazovaniya", Prikladnye problemy upravleniya makrosistemami, Pod red. Yu.S. Popkova, V.A. Putilova. T. 39], Knizhnyj dom «LIBROKOM», Moscow, pp. 397-402.

2. Ryzhenko AA, Ryzhenko NY, Khabibulin RS, Matveev NA (2014) "Method differentiable project in education system and training in State Fire Academy of EMERCOM of Russia", New 
information technologies in education: Collected papers ["Metod differenciruemogo skvoznogo proekta $\mathrm{v}$ sisteme obucheniya i podgotovki kadrov Akademii GPS MCHS Rossii", Novye informacionnye texnologii v obrazovanii: Materialy VII mezhdunar. nauch.prakt. konf.], FGAOU VPO «Ros. gos. prof.ped. un-t», Ekaterinburg, pp. 268-270.

3. Ryzhenko AA (2014) "A facet method of the analysis of statistical data on the fires in the territory of the Russian Federation", Materials of the 3rd international scientific and practical conference of young scientists and experts of "A problem of a technosphere safety - 2014": Collected papers ["Fasetnyj metod analiza statisticheskix dannyx po pozharam na territorii RF", Materialy 3-j mezhdunarodnoj nauchnoprakticheskoj konferencii molodyx uchenyx i specialistov «Problemy texnosfernoj bezopasnosti - 2014»], State Fire Academy of EMERCOM of Russia, Moscow, pp. 297-299.

4. Ryzhenko AA, Ryzhenko NY (2014) "Using tools $1 \mathrm{C}$ to coordinate professional work of the teacher of the State Fire Academy of EMERCOM of Russia", New information technologies in education: The collection of scientific works of the 14th international scientific and practical conference "New Information Technologies in Education": Collected papers ["Ispolzovanie instrumentariya platformy $1 \mathrm{~S}$ dlya koordinacii professionalnoj deyatelnosti prepodavatelya Akademii GPS MCHS Rossii", Novye informacionnye texnologii $\mathrm{V}$ obrazovanii: sbornik nauchnyx trudov 14-j mezhdunarodnoj nauchno-prakticheskoj konferencii «Novye informacionnye texnologii $\mathrm{V}$ obrazovanii» (Texnologii «1S» dlya povysheniya effektivnosti deyatelnosti organizacij obrazovaniya) 28-29 yanvarya $2014 \mathrm{~g}$. chast 2], JSC 1C-Publishing, Moscow, pp. 378-381.

5. Kolmogorov AN (2015) Available: http://www.kolmogorov.info (Accessed: 02.02.2015)

6. Vavilov NA (2015) Available: http://www.twirpx.com/file/1328797

(Accessed: 02.02.2015)
7. Butuzov SY, Prus YV, Smirnih EV, Ryzhenko AA, Ryzhenko NY, Eltemerova OV (2014) "Concept of formation uniform system of informing and notification population means EMERCOM of Russia": Collected works ["Koncepciya formirovaniya edinoj sistemy informirovaniya i opoveshheniya naseleniya sredstvami mchs rossii", Sbornik trudov], State Fire Academy of EMERCOM of Russia, Moscow, 163 p.

8. Ryzhenko AA (2014) Algebraic approach of the operated processes modeling of difficult systems. American Journal of Control Systems and Information Technology, 2014. - T. 4, No. 2. - pp. 17-21.

9. Ryzhenko AA (2015) Method of modeling of the operated processes of difficult systems // Modern informatization problems: Proceedings of the XX-th International Open Science Conference (Yelm, WA, USA, January 2015) / Editor in Chief Dr. Sci., Prof. O.Ja. Kravets. Yelm, WA, USA: Science Book Publishing House, 2015. - pp. 191-196.

10. Ryzhenko AA (2014) "About new approach to modeling processes management of complex security systems", Materials of the 23nd international scientific and technical conference "Security Systems - 2014": Collected papers ["O novom podxode $\mathrm{k}$ modelirovaniyu processov upravleniya kompleksnymi sistemami bezopasnosti", Materialy 23-j mezhdunarodnoj nauchno-texnicheskoj konferencii «Sistemy bezopasnosti - 2014»], State Fire Academy of EMERCOM of Russia, Moscow, pp. 29-33

11. Ryzhenko AA (2014) "Hierarchy management of security systems", Materials of the 23nd international scientific and technical conference "Security Systems - 2014": Collected papers ["Ierarxiya upravleniya sistemami bezopasnosti", Materialy 23-j mezhdunarodnoj nauchno-texnicheskoj konferencii «Sistemy bezopasnosti - 2014»], State Fire Academy of EMERCOM of Russia, Moscow, pp. 36-38. 